\title{
AFTER-SCHOOL ACTIVITIES AND ACADEMIC PERFORMANCE: EXPLORING ALTERNATIVE APPROACH TO EDUCATIONAL DEVELOPMENT IN NIGERIA
}

\author{
${ }^{1}$ Emmanuel Abiodun OGUNDIPE and ${ }^{2}$ Sunday Israel AKINDE, Ph. D \\ ${ }^{1}$ Graduate Assistant, Institute for the Environment and Sustainability (IES), Geography Department \\ College of Arts and Sciences, Miami University, USA. \\ ${ }^{2}$ Department of Sociology, Adekunle Ajasin University, Akungba, Akoko.
}

DOI: 10.46609/IJSSER.2020.v05i08.002 URL: https://doi.org/10.46609/IJSSER.2020.v05i08.002

\begin{abstract}
A reverse of side-effects of certain after-school activities on students could serve as an alternative means of educational development. Through a multistage procedure involving stratified and systematic techniques, data was collected from 196 secondary students. Weighted third terminal scores for 2015/2016 session and first terminal scores of 20016/2017academic year (making a total of four terms), were analyzed along with student-participants' responses using descriptive and inferential statistics. Findings indicate that as a side effect, street-hawking had a significant negative relationship on participants' academic performance $[\mathrm{r}(184)=-0.223, \mathrm{p}$ $<.01]$; that students who measure high on mobile or internet usage significantly performed less (Mean=580.43) academically among others. It is submitted that as students' academic performance decreases due to multiple activities and high interaction with internet, dismal academic performance could be reversed for improved educational development through committed monitoring of parents.
\end{abstract}

Keywords: .After-school Activities, Academic Performance, Educational Development, Environment.

\subsection{Introduction}

The nature and quality of activities that in-school children engage in after each day's school hours, seems to have implications for their academic performance. It is also noteworthy that determining the types and selecting goals for participation in after-school activities, depend 


\section{International Journal of Social Science and Economic Research}

ISSN: $2455-8834$

Volume:05, Issue:08 "August 2020"

much on the environment involved. After-school activities, depending on the environment concerned, refer to programmes or those things that a student or child of school age engages in after the school hours. The factor of the environment, as earlier mentioned, is significant in determining the nature of after-school activities available to students or children in both developed and developing countries [1][2]. In most developed countries, after-school activities are structured. This means they are formally organized with curricula of activities by local authorities, non-profit organizations, social and recreational agencies, faith-based organizations or covered by neighborhood/community managements or the government in order to cater for academic as well as developmental needs of students [3]. In fact, governments devote enormous resources to funding After School Programmes (ASPs)| or activities in developed countries.

The federal funding for ASPs, for example, in the USA, between 1998 and 2004, increased from $\$ 40$ million to over $\$ 1$ billion in the United States for the purpose of funding "No Child Left Behind Act of 2001" [4]. Some scholars believed that such students are more successful in later life [5] however; some others consider that too many activities might result in overparenting [6]. Some research has shown that structured after-school programmes can lead to better test scores, helping in home assignment completion, and higher grades (Joseph, Joseph \& Amy et al., 2010). Others have questioned its effectiveness especially with regard to school attendance [4]. However, it has been observed that certain activities have impacted students towards closing the achievement gap [7]

Structured after-school activities are meant to provide an extracurricular opportunity for students to develop their interpersonal aspect of life and potentials for future role they are likely to assume when they become full-grown. It is also a period they practicalize what they learn at school. Such structured activities are geared towards an all-round development of the child [8]. Sometimes, such activities are focused on maintaining academic levels and prevent the student's academic level from falling. It may focus on benefiting children who are at risk for school. Also, the impact sought may be towards the need for self- esteem or to increase the level of attachment of the student to the school [9]. While the above idea of after-school activities reflects what obtains in the advanced world, the same cannot be said in most developing societies where afterschool activities are unstructured. Unstructured activities are after-school engagements which are not formally organized, neither are they directed by curriculum of activities or carried on by local, not-for-profit agencies, but are time-engaging ventures which are mostly borne out of socio-cultural and socioeconomic impulses of the environment. Thus, continental differentials influence to a large extent the type and quality of after-school activities students undertake [10].

In the sub-Saharan African context, unstructured after-school activities are mostly reflections of the challenges of the environment and levels of development. Observance of most of such activities by the youth is sometimes viewed as mark of obedience to parents which to all intents 


\section{International Journal of Social Science and Economic Research}

ISSN: $2455-8834$

Volume:05, Issue:08 "August 2020"

and purposes are meant to shore up family income in order to cushion the effects of harsh economic conditions in the country concerned. The socio-cultural expectations coincide with the economic exigencies of the moment, thus displaying the typical high ecological influences of the African life [11]. The western concept of after-school activities is mirrored by Abraham Maslow's hierarchies of human needs in which the higher-order needs of social belongingness (though, partly), self-esteem and self-actualization are attained since the lower-order hierarchies are already met, as assumed [12][13].The lower-order needs of physiological content, safety and some aspect of social belongingness [14][15]reflects the ecological profile of African life in which need for food and shelter is still very crucial. Hence, this study focuses mostly, afterschool activities that are different from western concept as they are free from institutional sponsorship compared to their western counterparts.

In African setting, after-school activities such as street hawking, going to meet parents on the farm or staying with parent in the shop, are meant mostly to augment household income in the short-run. The activities comprising part-time vocational training (learning a trade, e.g. tailoring, motor repair, etc) are responses to economic circumstances in the long-run and as insurance against unemployment in the future. This practice is very common these days when students after the day's school, go to such places where they learn phone repairs, mechanics, tailoring, barbing, etc. These activities, except extramural coaching classes, express their side-effects on academic performance as students consume part of the after-school period on non-academic endeavours. The long time effect of such has the tendency to generate falling standard of education. Falling standard in education has implications for the ever-recurring question of educational development in the country [16].

Simply put, educational development refers to increasing capacity of a society to efficiently deploy its resources, both human and material, towards educating its citizens in a consistent way. The increasing capacity mirrors constant improvements on societal culture, mores, and normative system to creating the needed enabling environment for educational efforts to thrive across all sectors of the society [17]. However, where primordial values and sentiments constitute bottleneck to attainment of envisioned development levels in education as in the case with environmentally deterministic value of using children as the 'economic beast of burden' (as argued by the current study), this practice will not only negate expectations in the drive towards improved standard in education, but continue to fritter away the meager, much-needed resources available for other sectors of economy. A nation is said to attain educational development to the extent it is able to constantly improve on its methods, practices; and systems and reduce on a consistent basis, real or probable obstacles towards achieving set objectives for educational attainment of its citizens. 


\section{International Journal of Social Science and Economic Research}

ISSN: $2455-8834$

Volume:05, Issue:08 "August 2020"

In spite of the huge commitments both by parents and the government at all levels, annually; students sometimes perform below expectations especially in some public examinations [18]. This trend is noticeable in the number of students who sit for public exams like JCE/SSCE/NABTEB, UTME or other related qualifying examinations and the number that make five credit passes (e.g in the JCE/ SSCE/NABTEB) at one sitting (and those who make impressive UTME scores for placement in colleges of education, polytechnics and universities in the country. These facts were confirmed by certain international institutionssuch as Africa Check in [19]; UNESCO-UNEVOC in[20]; World Education Services in [21] and National Bureau of Statistics in their report of [22] and [23]. More puzzling is the fact that as the government and parents expend energy towards educating their children they may inadvertently act (through those after-school activities) in ways that negate such efforts, thereby defeating the goal of overall national educational development [24].

The educators as well, whose duty centers on implementing government policies and reflecting parents' efforts, often fail to realize the negative impact of certain after-school activities undermining such efforts and as such, are yet to exert adequate efforts towards arresting the trend. Neglect of this new approach (of checkmating influence of negative after-school activities on students) may result in the failure to attain enviable educational development levels in the country. This, if it remainsunchecked, has the tendency to obstruct the country's appreciable strides in educational development. Secondly, it appears that street hawking has remained the much-investigated issue in after-school activity research. This investigation adopts a comprehensive approach to issue by focusing on common after-school activities as are likely to negatively affect academic performance of students at large. Thirdly, as this study considers the continental differences in after-school activities between sub-Saharan Africa and continental Europe and America through the consideration of the peculiarities of each continent and levels of development, it does fill some existing gap within the scanty after-school literature as it concerns the African context.

This study intends to answer some pertinent questions among which are: to what extent do students engage in the various forms of after-school activities? What are the effects some afterschool activities such as street-hawking, farm work, keeping shop with parents, coaching class/personal studying and part-time apprenticeship, have on students' academic performance?. What are the outcomes if students combine two or more non-academic activities; and to what extent could internet/mobile phone usage affect academic performance of students if not controlled. As part of objectives of this study, the extent to which students get involved in afterschool activities will be examined; students' academic performance levels in relation to such above-mentioned after-school activities e.g. hawking will also be examined, in order to draw a comparison between academic performance levels of students who engage in such activities and 


\section{International Journal of Social Science and Economic Research}

ISSN: $2455-8834$

Volume:05, Issue:08 "August 2020"

those who do not. Effects of combining several after-school activities will be examined; and lastly, the study will examine the extent to which internet usage may affect performance of students.

\subsection{Methodology}

Data for this study was collected in 3 secondary schools; namely, Community Comprehensive High school, Apex Secondary School and Best Time College; located in Akungba, Ondo State. Purposive technique informed the selection of Junior Secondary School (JSS) classes 1, 2 and 3, being the most involved groups (as empirical observation has shown) in the after-school activities under consideration. A multistage sampling technique involving stratification of the JSS 1-3 classes, from which only JSS 2 and JSS 3 were selected. In order to determine academic performance, students' raw scores for the third term 2015/2016 and first terminal scores of 2016/2017 sessions were added and divided by 2. Systematic sampling technique was further used to finally select 196 students from a total of 396 students from the 3 schools. There are 3 schools comprising 2 private and 1 public schools. In order to reflect the effects of internet /phone devices, selection of the private schools was purposively restricted to day schools, as boarding schools do not permit the use of internet/mobile phone devices (to limit the effect of intervening variables). The breakdown of the sample comprised 88(44.7\%) JSS 2 and 109(55.3\%) JSS 3students. Five after-school activities were identified; namely hawking, farming, trade learning, home study, and shop-keeping.

The instrument of data collection was a 22-item questionnaire divided into 3 sections. Sections $\mathrm{A}$ and $\mathrm{B}$ were developed by this study. The questionnaire schedule comprised of 4 sociodemographic items and 5 questions on the direct variables focusing on hypothesized relationships of the study. Section $\mathrm{C}$ was a standardized, severally validated questionnaire on internet usage developed by Young [25]. This was modified to 13 questions for easy comprehension by the students. In all, the questions were kept as simple and minimum as possible considering the ability of semi-urban students' experience in social research activity. The basic questions were nominal while Section B comprised questions on involvement in different after-school activities. The questions were based on ordinal scale (e.g. Questions= "Do you help your parents to sell things after school hours?'. Options= 'always' (2), 'occasionally (1)'and 'never' (0). The secondary data comprised the raw scores from the students' report cards made available by the school authorities.

To test the hypotheses, Simple and Multiple Regression analyses, One-Way Analyses of Variance (ANOVA), Pearson Product Moment Correlation (PPMC), Independent sample T-test and ANCOVA, were used. While the independent variable was represented by the various afterschool activities, students' academic performance constitutes the only dependent variable of the 
International Journal of Social Science and Economic Research

ISSN: 2455-8834

Volume:05, Issue:08 "August 2020"

study. Internet usage constituted the intervening variable of the study. The individual student's weighted score constitutes the student's performance for the two academic periods. The computation appears thus:

Academic Performance $(\mathrm{AP})=\%$ Summary of the Previous Third Term $(\mathrm{PTT})+\%$ Summary of the Current Term (CT) / 2:

$$
\begin{gathered}
\text { Where } \mathrm{T}=\text { term; PTT }=1^{\text {st }} \mathrm{t}+2^{\text {nd }} \mathrm{t}+3^{\mathrm{rd}}+\mathrm{CT}\left(4^{\text {th }} \mathrm{T}\right) \\
\mathrm{AP}=\text { Summation of PTTs }+\mathrm{CT} / 2
\end{gathered}
$$

\subsection{Analyses and Results}

As Table 1 indicates, $47.7 \%$ of the respondents are male, while $52.3 \%$ are female. This justifies the random selection of participants such that both male and female students are duly represented. It is also observed that $69 \%$ of the respondents fall within the age range of 10 and 14 years while $26.9 \%$ within the age range of 15 and 19 years. On the sampled schools, 51.3\% are from Community Comprehensive High School, Akungba, 17.8\% from Best Time College, Akungba, while 31\% are from Apex Secondary School, Akungba. The distribution shows that almost one-half of the sample (48.7\%) is from private schools. Over $44 \%$ of the respondents are in JSS 2, while $55.3 \%$ are in JSS 3.

Table 1: Respondents Basic characteristics

\begin{tabular}{llcc}
\hline Factors & Options & Frequency & \% \\
\hline Gender & Male & 94 & 47.7 \\
& Female & 103 & 52.3 \\
& Total & 197 & 100.0 \\
\hline Age & 10 - 14 years & 136 & 69.0 \\
& 15 - 19 years & 61 & 31.0 \\
& Total & 197 & 100.0 \\
\hline School & Community Comprehensive & 101 & 51.3 \\
& High School, Akungba & & \\
& Best Time College, Akungba & 35 & 17.8 \\
& Apex Secondary & 61 & 31.0 \\
& School,Akungba & & \\
& Total & 197 & 100.0 \\
\hline Class & JSS2 & 88 & 44.7 \\
& JSS3 & 109 & 55.3 \\
& Total & 197 & 100.0 \\
\hline
\end{tabular}


International Journal of Social Science and Economic Research

ISSN: 2455-8834

Volume:05, Issue:08 "August 2020"

Research Question 1: To what extent do students engage in the various forms of after-school activities?The extent of students' involvement in after school activities is presented in Table 2. Table 2 indicates that $41.6 \%$ always help their parents to sell things after school hours; $17.3 \%$ do so occasionally, while $41.1 \%$ hardly do. More than $16 \%$ go to the farm to meet parents after school hours; $24.9 \%$ do so occasionally, while $58.9 \%$ never do. While $45.2 \%$ do not stay in the shop with their parents after school hours; $16.2 \%$ do so occasionally while $38.6 \%$ do not. Over $87 \%$ of the students do more of reading and home assignment after the school hours, $9.6 \%$ do so occasionally while $3 \%$ do not. This implies that almost all students do some kind of reading and homework after school hours, even if they still engaged in some other non-academic activities.

Table 2: Involvement in After-school Activities

\begin{tabular}{lccccc}
\hline \multicolumn{1}{c}{ Items } & \multicolumn{5}{c}{ Response } \\
& & Always & Occasionally & Never & Total \\
\hline I help my parents to sell things after & $\mathrm{F}$ & 82 & 34 & 81 & 197 \\
school hours & $\%$ & 41.6 & 17.3 & 41.1 & 100.0 \\
\hline I go to the farm to meet my parents & $\mathrm{F}$ & 32 & 49 & 116 & 197 \\
after school hours & $\%$ & 16.2 & 24.9 & 58.9 & 100.0 \\
\hline I stay in the shop with my parents after & $\mathrm{F}$ & 89 & 32 & 76 & 197 \\
school hours & $\%$ & 45.2 & 16.2 & 38.6 & 100.0 \\
\hline I read my books and do my homework & $\mathrm{F}$ & 172 & 19 & 6 & 197 \\
after school hours & $\%$ & 87.3 & 9.6 & 3.0 & 100.0 \\
\hline I go to where I learn work (e.g. phone & $\mathrm{F}$ & 32 & 23 & 142 & 197 \\
repair, etc.) after the school hours & $\%$ & 16.2 & 11.7 & 72.1 & 100.0 \\
\hline Average Total & $\mathrm{F}$ & 82 & 31 & 84 & 197 \\
& $\%$ & 41.6 & 15.8 & 42.6 & 100.0 \\
\hline
\end{tabular}

Finally, $16.2 \%$ of the respondents are into vocational training after the school hours, $11.7 \%$ do so occasionally, while $72.1 \%$ do not. It could be inferred that $41.6 \%$ of the respondents always engage in after school activities, $15.8 \%$ does occasionally, while $42.6 \%$ hardly do.

Research Question 2: Is there any relationship between after school activities and academic performance of students?

In Table 3, students who never engaged in hawking after school hours (Mean=647.67) had the highest academic performance, while those who scored the least did not (Mean=554.28). This implies that concentration on hawking after school hours may affect students' academic performance. Similar results hold across other after-school activities such that those who never 
International Journal of Social Science and Economic Research

ISSN: 2455-8834

Volume:05, Issue:08 "August 2020"

engaged in them tend to outperform those who did. Those who hardly go to the farm but concentrated more on their studies, performed best (Mean=644.29), while the least performers did not (Mean=503.70). Those who never stayed in parent's shop performed best $(M=643.56)$, while the least-performers occasionally did (Mean=567.59). Similarly, students who never engaged in part-time apprenticeship performed best academically (M613.09), while those who learnt a trade, constituted the least performers (Mean=555.94). Those who studied more after school hours performed best (Mean=628.17), while the least-performers did not (Mean=595.39).

Table 3: Mean and Standard Deviation (SD) Summary of Academic Performance and After-School Activities

\begin{tabular}{llcccc}
\hline After school activities & & Always & Occasionally & Never & Total \\
\hline I help my parents to sell & $\mathrm{N}$ & 82 & 34 & 81 & 197 \\
things after school hours & Mean & 554.28 & 582.03 & 647.67 & 597.47 \\
& $\mathrm{SD}$ & 193.44 & 243.89 & 199.21 & 208.66 \\
\hline I go to the farm to meet my & $\mathrm{N}$ & 32 & 49 & 116 & 197 \\
parents after school hours & Mean & 503.70 & 547.857 & 644.29 & 597.47 \\
& $\mathrm{SD}$ & 177.29 & 209.11 & 204.39 & 208.66 \\
\hline I stay in the shop with my & $\mathrm{N}$ & 86 & 32 & 76 & 197 \\
parents after school hours & Mean & 568.85 & 567.59 & 643.56 & 597.47 \\
& $\mathrm{SD}$ & 199.58 & 240.63 & 199.01 & 208.66 \\
\hline I read my books and do my & $\mathrm{N}$ & 172 & 19 & 6 & 197 \\
homework after school hours & Mean & 628.17 & 606.58 & 595.39 & 597.47 \\
& $\mathrm{SD}$ & 147.22 & 212.73 & 210.86 & 208.66 \\
\hline I go to where I learn work & $\mathrm{N}$ & 32 & 23 & 142 & 197 \\
(e.g; tailoring) after the school & Mean & 558.01 & 555.94 & 613.09 & 597.47 \\
hours. & $\mathrm{SD}$ & 154.58 & 234.43 & 214.04 & 208.66 \\
\hline
\end{tabular}

This finding could be attributed to the fact that majority of the students who engaged in academic-related after-school activities also engaged in some other forms of after-school activities, thus affecting their performance.

Research Question 3: Is there any difference between the performances of students who personally study at home (or attend coaching classes) after school hours and those who engage in other non-academic activities?

Table 4 indicates that students who concentrated more on academic activities after school hours $(\mathrm{M}=653.967)$ outperformed those who concentrate more on other activities $(\mathrm{M}=580.739)$. This 
implies that although it cannot always be 'all work without play', such students however gave priority to their studies than other activities after the school hours.

Table 4: M\&SD Summary between Academic and Non-academic Activities

\begin{tabular}{llcc}
\hline $\begin{array}{l}\text { After School } \\
\text { Hours Activities }\end{array}$ & Mean & N & $\begin{array}{c}\text { Std. } \\
\text { Deviation }\end{array}$ \\
\hline Other activities & 580.739 & 152 & 208.4862 \\
Academic only & 653.967 & 45 & 201.3586 \\
Total & 597.466 & 197 & 208.6597 \\
\hline
\end{tabular}

Research Question 4: Will a student who combines two or more non-academic activities indicate higher performance in his studies?

Table 5: M\&SD Summary between Academic performance and Engagement in less than two or more Non-academic Activities

\begin{tabular}{lccc}
\hline $\begin{array}{l}\text { Engagement in } \\
\text { After school } \\
\text { activities }\end{array}$ & Mean & N & Std. Deviation \\
\hline Less than two & 636.622 & 82 & 202.0736 \\
Two and above & 569.546 & 115 & 209.6513 \\
Total & 597.466 & 197 & 208.6597 \\
\hline
\end{tabular}

Results in Table 5 indicates that students who engage in less than two after-school non-academic activities seem to perform better (Mean=636.622) compared to those who engage in two or more non-academic activities after school hours (Mean=569.546). This implies that students who combine two or more non-academic activities may not perform well in their studies.

Research Question 5: Do students who engage in heavy internet or mobile phone browsing perform optimally in their course of studies? 
International Journal of Social Science and Economic Research

ISSN: 2455-8834

Volume:05, Issue:08 "August 2020"

Table 6: M\&SD Summary between students' Academic performance in relation to Internet/mobile phone Usage

\begin{tabular}{llrr}
\hline $\begin{array}{l}\text { Mobile/ } \\
\text { Internet } \\
\text { Usage }\end{array}$ & Mean & \multicolumn{1}{c}{ N } & $\begin{array}{c}\text { Std. } \\
\text { Deviation }\end{array}$ \\
\hline Low & 616.131 & 94 & 204.4129 \\
High & 580.432 & 103 & 212.0168 \\
Total & 597.466 & 197 & 208.6597 \\
\hline
\end{tabular}

In Table 6, students who interact less with the internet or mobile phone devices perform better (Mean=616.131) compared with those who are high users (Mean=580.432). This implies that unrestrained use of mobile phone or internet facilities may decrease academic performance of students.

\section{Test of Hypotheses}

Hypothesis 1: Students who engage more in academic activities after school hours will significantly perform better academically than those who engage in non-academic activities.

In Table 8, hawking after school hours is significantly related to academic performance on a negative note $[\mathrm{r}(195)=-20, \mathrm{p}<.01]$. This implies that an increase in the involvement of students in hawking after school hours, results in a somewhat decrease in their academic performance. Similarly, engaging in farm activities after school hours is negatively related to students' academic performance $[\mathrm{r}(195)=-27, \mathrm{p}<.01]$. As students engage more in farm work after school hours, the less they tend to perform academically. The relationship between staying in the shop with parents and academic performance is such negatively significant $[\mathrm{r}(195)=-16, \mathrm{p}<$ $.05]$, reflecting an inverse relationship.

Table 7: Independent T-test showing the influence of after- school activities on students' academic performance

\begin{tabular}{llcccccc}
\hline & After School & & & & & & \\
& Hours Activities & N & Mean & SD & df & t & p \\
\hline Academic & Others & 152 & 580.74 & 208.49 & 195 & -2.09 & $<.05$ \\
Performance & Academics solely & 45 & 653.97 & 201.36 & & & \\
& & & & & & & \\
\hline
\end{tabular}


Table 7 indicates that after-school activities significantly influence students' academic performance $[\mathrm{t}(195)=-2.09, \mathrm{p}<.05]$. Those who focus more on academic activities after school hours perform better in their studies (Mean=653.97) compared to those who are engaged in other non-academic activities (Mean=589.74). This result confirms the formulated alternate hypothesis 1 and it is thus accepted.

Hypothesis 2: There is no significant relationship between each of the after-school activities, and students' academic performance.

It is observed in Table 8 that hawking after school hours is significantly related to academic performance on a negative note $[\mathrm{r}(195)=-20, \mathrm{p}<.01]$. This implies that an increase in the involvement of students in hawking after school hours, results in a decrease in their academic performance. Similarly, engaging in farm activities after school hours is negatively related to students' academic performance $[\mathrm{r}(195)=-27, \mathrm{p}<.01]$. As students engage more in farm work after school hours, the less they tend to perform academically. The relationship between staying in the shop with parents and academic performance is such negatively significant $[\mathrm{r}(195)=-16, \mathrm{p}$ $<.05]$, reflecting an inverse relationship.

Table 8: Correlation Matrix showing the relationship between students' after school activities and their academic performance

\begin{tabular}{|c|c|c|c|c|c|c|c|c|}
\hline Variables & Mean & SD & 1 & 2 & 3 & 4 & 5 & 6 \\
\hline $\begin{array}{l}\text { 1. I help my parents to } \\
\text { sell things after school } \\
\text { hours }\end{array}$ & 1.99 & .91 & 1 & & & & & \\
\hline $\begin{array}{l}\text { 2. I go to the farm to } \\
\text { meet my parents after } \\
\text { school hours }\end{array}$ & 2.43 & .76 & $.47^{* *}$ & 1 & & & & \\
\hline $\begin{array}{l}\text { 3. I stay in the shop with } \\
\text { my parents after school } \\
\text { hours }\end{array}$ & 1.93 & .92 & $.48^{* *}$ & $.19^{* *}$ & 1 & & & \\
\hline $\begin{array}{l}\text { 4. I read my books and } \\
\text { do my homework after } \\
\text { school hours }\end{array}$ & 1.16 & .44 & .04 & .03 & .00 & 1 & & \\
\hline $\begin{array}{l}\text { 5. I go to where I learn } \\
\text { work (e.g; tailoring, } \\
\text { welding, motor } \\
\text { mechanic) after the } \\
\text { school hours. }\end{array}$ & 2.56 & .76 & $.25^{* *}$ & $.33^{* *}$ & $.22^{* *}$ & -.01 & 1 & \\
\hline $\begin{array}{l}\text { 6. Academic } \\
\text { Performance }\end{array}$ & 597.47 & 208.66 & $-.20^{* *}$ & $-.27^{* * *}$ & $-.16^{*}$ & -.03 & -.11 & 1 \\
\hline
\end{tabular}


International Journal of Social Science and Economic Research

ISSN: $2455-8834$

Volume:05, Issue:08 "August 2020"

$* * \mathrm{p}<.01, * \mathrm{p}<.05, \mathrm{~N}=19$

The result also reveals that relationship between reading after school hours and academic performances was not significant $[\mathrm{r}(195)=-.03, \mathrm{p}>.05]$. This could be related to the fact that most of the students that signified that they study their books after school hours also did engage in one form of after-school non-academic activity or another. Lastly, it is also noted that learning a work after school hours do not significantly predict their after school hour activities [r (195)= $.11, \mathrm{p}>.05]$. The findings partially confirm hypothesis 1 .

Hypothesis 3: Students who combine two or more non-academic activities after school hours are not likely to perform well in their studies.

Table 9 indicates that students who engage in less than two non-academic after-school activities outperform (Mean=656.55; $\mathrm{SD}=201.83$ ) those who engage in two or more activities (Mean=569.55; SD=209.65). This implies that the more engaged students are with non-academic after school activities, the more are they likely to perform poorly in their academics [ $t(145)=$ $2.09, \mathrm{p}<.05]$.

\section{Table 9: Independent T-test showing influence of combined non-academic activities after school hours on Academic performance}

\begin{tabular}{|ll|r|c|c|c|c|c|}
\hline & $\begin{array}{l}\text { Non-Academic } \\
\text { after school } \\
\text { Activities }\end{array}$ & N & Mean & SD & df & t & p \\
\hline $\begin{array}{l}\text { Academic } \\
\text { Performance }\end{array}$ & $\begin{array}{l}\text { Less than two } \\
\text { Two or more }\end{array}$ & 32 & 656.547 & 201.833 & 145 & 2.09 & $<.05$ \\
\hline
\end{tabular}

Hypothesis 4: Students who measure high on mobile or internet usage will significantly perform less academically compared to those that measure low on internet/mobile usage.

Table 10 reveals that mobile/ internet usage has significant influence on students' academic performance $(\beta=0.14, \mathrm{t}=1.98, \mathrm{p}<.05)$. This was such that the higher the utilization of mobile or internet device by students after school hours, the higher are likely to experience lower academic performance. The findings indicated that 3\% variance was attributed to students' usage of mobile or internet devices in the total changes observed in academic performance. This confirmed the formulated hypothesis 4 . 
International Journal of Social Science and Economic Research

ISSN: 2455-8834

Volume:05, Issue:08 "August 2020"

Table 10: Simple Regression showing the influence of mobile/ internet usage on Academic Performance

\begin{tabular}{lccccccc}
\hline Variables & $\mathbf{B}$ & $\mathbf{t}$ & $\mathbf{p}$ & $\mathbf{R}$ & $\mathbf{R}^{2}$ & $\mathbf{d f}$ & $\mathbf{F}$ \\
\hline $\begin{array}{l}\text { Mobile/ internet } \\
\text { usage }\end{array}$ & -.14 & -1.98 & $<.05$ & .13 & .03 & 1,195 & $3.547^{*}$ \\
\hline
\end{tabular}

Note: $* \mathrm{p}<0.05$

Hypothesis 5: Students' after-school activities will have significant influence on their academic performance while controlling for the usage of internet/mobile phones.

It is observed in Table 11 that when use of internet/mobile device is controlled for, after-school activities still influence students' academic performance $[F(1,194)=4.065, p<.05]$, such that students who engage in academic activities, majorly, after school hours, tend to perform better than those who focus on other activities. This result confirmed hypothesis 4 and it is thus accepted.

Table 11: 2 X 2 ANCOVA indicating the influence of after-school activities on academic performance while controlling for the usage of internet/mobile phones

\begin{tabular}{lccccc}
\hline Source & SS & df & MS & F & Sig. \\
\hline (Control) internet/mobile & 50302.366 & 1 & 50302.366 & 1.176 & .279 \\
usage & & & & & \\
After-school activities & 173852.949 & 1 & 173852.949 & 4.065 & $<.05$ \\
Error & 8297133.655 & 194 & 42768.730 & & \\
Total & 8533620.062 & 196 & & & \\
\hline
\end{tabular}

Hypothesis 6: Gender, age, engagement in after school activities and internet usage significantly predict academic performance among students

In Table 12, further analysis was conducted to test the joint prediction of gender, age, engagement in after school activities and mobile/internet usage on academic performance. This revealed the independent and joint contributions of each of the major study variables on academic performance. The distribution indicates that gender did not influence academic performance $(\beta=0.03, t=0.35, p>.05)$. Age of students influenced their academic performance $(\beta=-0.16, t=-2.16, p<.05)$ and this was such that older ones performed less compared to younger ones. On the major variables, engagement in after school activities significantly predicted academic performance $(\beta=-0.19, \mathrm{t}=-2.92, \mathrm{p}<.05)$. This was such that those who 
International Journal of Social Science and Economic Research

ISSN: 2455-8834

Volume:05, Issue:08 "August 2020"

engaged more in some after- school activities performed less in academics compared to when they are not involved with such activities. Lastly, the utilization of mobile device and internet resources affected the academic performances of students $(\beta=-0.20, \mathrm{t}=-3.27, \mathrm{p}<.01)$ in such a way that those who indiscriminately utilized mobile or internet device performed less in their academics. Jointly, the variables contributed a significant variance of $16 \%$ to the total variance observed in academic performance $[\mathrm{R}=.25, \mathrm{R} 2=.16, \mathrm{~F}(5,185)=4.42, \mathrm{p}<.05]$.

Table 12: Multiple Regression Showing the Predictions on Students' Academic Performance

\begin{tabular}{lccccccc}
\hline Variables & $\boldsymbol{\beta}$ & $\mathbf{t}$ & $\mathbf{p}$ & $\mathbf{R}$ & $\mathbf{R}^{2}$ & $\mathbf{d f}$ & $\mathbf{F}$ \\
\hline & & & & .25 & .16 & 5,185 & $4.42^{* *}$ \\
Gender & .03 & .35 & $>.05$ & & & & \\
Age & -.16 & $-2.16^{*}$ & $<.05$ & & & & \\
Engagement in After & -.19 & $-2.92^{*}$ & $<.05$ & & & & \\
school activities & & & & & & & \\
Mobile/ Internet usage & -.20 & $-3.27^{* *}$ & $<.05$ & & & & \\
\hline
\end{tabular}

\subsection{Discussion of Findings}

The main objective of this study is to determine how effective various local and national efforts could yield more positive educational development outcomes through proper handling of afterschool activities. This study is more of an exploratory effort; consequently, there is yet scanty specific empirical studies in areas like, examining the impact of combination of studying with two or more nonacademic after-school activities on performance as expressed in hypothesis 3 . Largely, confirmation of some results would follow a general pattern in trying to situate findings within the body of empirical literature.

Findings revealed that mostof the respondents engaged in one form of after-school activities. These activities differed significantly from those structured and institutionally sponsored After School Progammes found in the western world [3]. The activities were culturally and environmentally determined as mentioned earlier. With the exception of studying after school hours, other activities had the tendency to impact negatively on the students. For example, street hawking could hinder a student from being her best academically. When correlated with academic performance, it displayed a negative impact. This effect had relevance with Ubah[24] who studied the effects of street hawking on the academic performance of students in social studies in junior secondary schools in Nassarawa State, Nigeria. His study revealed a significant 


\section{International Journal of Social Science and Economic Research}

ISSN: $2455-8834$

Volume:05, Issue:08 "August 2020"

difference between academic performance of students who engaged in street hawking after school hours and their counterparts who did not.

As mentioned earlier, students are found in the streets hawking before going to school each day, in the morning and more at evenings after the school hours. In addition to the streets, they are found at motor parks with trays on their heads and also at road sides chanting their goods. At evenings, they sit beside the road taking some rest and charting with one another while their ears are opened to short calls either from motorists or other road users. It may be asked: what time could they have after such an activity to attend to their studies? This is because at the end of such activities they are worn out and may even find it difficult to attend their home assignments. While our students find it difficult to attend to assignments, students exposed to right ASPs participate in after-school activities that link schooling with academic success outcomes such as motivation to learn, decreased absenteeism, lower levels of aggression and violence and lower suspension rates, promptness at assignment submissions and improved grades [26][27][28].

Students who concentrate more on academic activities after school hours (Mean=653.967) outperform those who concentrate more on other activities (Mean=580.739) when their mean differences are compared. This result finds support in Buchmann [29] who found positive impacts of private tutoring on student academic performance in Kenya. He concluded that private tutoring reduced the chance of grade repetition and increased student academic performance. The overall effect of such arrangement is to add value to formal school efforts. This kind of arrangement is very common among the educated parents/guardians in urban and semi-urban settings like Akungba in Ondo state, Nigeria. However, such considerations are sometimes vitiated by the socioeconomic circumstances of the environment concerned.

Rasberry, Lee \& Robin et al.,[30] found in a study conducted in the United States that 11 out of 14 correlational studies of physical activity during the school day demonstrate a positive relationship to academic performance. Such studies suggest that time spent to engage on physical activity is related not only to a healthier body but also to a healthier mind. It needs be asked: Which type of physical activity? Is it hawking?, or going to farm to meet parents? It has also been found that moderate-intensity physical activity may increase neural and behavioral concomitants associated with the allocation of attention to a specific cognitive as results of a study conducted in the USA [31]. However, the current nature and state of development of our after-school programmes (e.g. in Nigeria) could hardly enable that, at present!

High academic performance is correlated with low/restrained usage of internet resources. In line with Agil\& Ahmad [32] who opined that internet carries together various information and services which plays a vital role in teaching, research and learning process in academic institution. However, the internet usage has also done more harm than good to students in their 


\section{International Journal of Social Science and Economic Research}

ISSN: $2455-8834$

Volume:05, Issue:08 "August 2020"

area of studying online and general browsing. This result is further supported by Ahmed \&Qazi,[33] who noted in a study of youth in UAE that internet in all its forms has effected a major change in the culture and lifestyle of people, particularly of the youth and that many of the prevailing problems afflicting the youth including poor performance at schools are a direct consequence of the big change that has struck social culture in some societies. The result added that sophisticated devices, such as 'iPad,' pose a new challenge to Emirati families with some complaining that "iPad has stolen their kids from them" as these devices divert them from their daily studies and completing their homework.

While several studies found no significant relations between heavy internet use and academic performance [34][33][35][36], a number of studies have found a negative impact that social network participation has on students' academic performance. For example, in multiple studies in 2000 and 2003.Malaney[37] found that some students reported that their grades had suffered as a result of too much time spent on social media. Evidence of a continuing drop of grades among students due to excessive use of social networking was reported by Banquil et al., [38] Some studies have reported a significant negative relation between Facebook use and academic performance such as drop in students' grades and lack of time as result of social networking participation[39][34][40][38].

\subsection{Conclusion}

This study sought to examine the antithetical relationship between academic performance and some non- academic activities in the Nigerian environment; and to verify the extent to which this could influence performance standard in educational development in the country. As difficult as some of these activities may seem, they sometimes are 'necessary evils' in that they are geared towards augmenting family income given the dwindling monthly and seasonal incomes from the parents who are mainly civil servants and peasant farmers. The government at all levels have crucial role to play in ensuring sustainable socioeconomic development that would significantly scale down reliance on after-school activities that bother on compulsory augmentation of family incomes through children towards mitigating harsh socioeconomic conditions in families. This is more so as majority of students that participate in some of these after-school activities are under-age, mostly ages 10-17 years. On this note, educational Non- Governmental Organizations and other advocacy groups as well as relevant government agencies should collaborate to push legislations that would enlarge the scope of forms of child abuse and child labour provisions with a view to defining and limiting the scope of activities under- age could be exposed to.

Students who focus more on academic activities after school hours performed better in their studies compared to those who engaged in other non-academic activities. That can be more effective where school counselors and officers in the Parent-Teacher Associations (PTAs) 


\section{International Journal of Social Science and Economic Research}

ISSN: $2455-8834$

Volume:05, Issue:08 "August 2020"

encourage students and parents on proper academic and after-school balance to enhance a smooth overall development of students. Students who engage in less hawking but study more after school hours had the highest academic performance. A similar trend is observed with regards to all non- academic activities in their effects on academic activities. That means that where it becomes inevitable to engage students in some after-school activities in order to augment family income, educators should counsel parents to exercise caution on the nature and scope of such involvement so as not to jeopardize the social and educational development of the child.

Students who concentrated more on academic activities after school hours tend to outperform those who concentrated more on other activities. The extent of involvement in non-academic activities after school tends to have effect on academic performance. Hence, students who engage in less than two after-school non-academic activities perform better academically compared to those who engage in two or more. This can be further ensured as parents exercise restraint in their use of youths or wards in laborious and time-consuming after-school activities but sparingly on long vacations. The massive influence of internet or mobile phone use on academic performance, both positively and negatively, was observed. Unrestrained use of mobile phone or internet facilities may decrease academic performance of students. Since students who interact less with the internet or mobile phone devices perform better compared with those who are high users, parents are to monitor and control the use of social networking devices by their youth.

This study has struck on two main areas. First, it has revealed a marked difference between the concept of after-school activities or programmes between western societies and sub-Saharan Africa. At present, there seem not to be proper presence of 'after school programs' in the region as the region's environmentally-driven after-school activities are unplanned, unstructured and unsupported by any institutional efforts. While our concept of after-school programmes should be home-grown as against unfettered adoption of the western model, there is urgent need to enhance educational development in the continent through well planned and state-supported after-school programmes. Two, this study is limited by inadequate inclusion of extraneous variables in the analyses though are important. There is no way a single study could accommodate all there is to be studied. Indeed, there are additional intervening variables, such as attending church programmes, casual participation in local sporting events and others. Regrettably, only internet usage was focused. The purpose here is not to examine in detail such issues which are better suited for future studies on this subject. 
International Journal of Social Science and Economic Research

ISSN: 2455-8834

Volume:05, Issue:08 "August 2020"

\section{REFERENCES}

[1] Huntington, H. P. (2000). Using traditional ecological knowledge in science: Methods and applications.Ecollogical Society of America, 10 (5), pp.1270-1274.

[2] Gross, E. F. (2004). Adolescent internet use: What we expect, what teens report. Journal of Applied Developmental Psychology 25(6), pp.633-649. .

[3] Simonton, S (2017). When Schools and Nonprofits Collaborate with Faith-based Organizations. Available at: http://youthtoday.org/contact-staff-reporter-stell-simonton/ (Accessed 4 September 2018).

[4] Kremer, K. P., Maynard, B.R., Polanin, J.R., Vaughn, M.G. and Sartesc, C.M. (2015). Effects of after-school programs with at-risk youth on attendance and externalizing behaviors: A systematic review and meta-analysis. Journal of Youth and Adolescence, 44(3), pp.616-636.

[5] Hirsch, B. J. (2011). Learning and Development in After-School Programs.Phi Delta Kappan, $92(5)$, pp. 66-69.

[6] Levine, M. (2006). The price of privilege: How parental pressure and material advantage are creating a generation of disconnected and unhappy kids. New York, NY, US: HarperCollins Publishers.

[7] Gutman, Leslie Morrison \&Midgley, Carol. (2000). The role of protective factors in supporting the academic achievement of poor African American students during the middle school transition. Journal of Youth and Adolescence, 29 (2), 223-249.

[8] Gardner, M., Roth, J., and Brooks-Gunn, 1. (2008). Adolescents' participation in organized activities and developmental success 2 and 8 years after high school: Do sponsorship, duration, and intensity matter? DevelopmentalPsychology, 44(3), pp. 814-830.

[9] Cosden, M., Morrison, G,, Gutierrez, L. and Brown, M. (2004). The effects of homework programs and after-school theory activities on school success.Theory into practice, 43, (3), pp. 220-236.

[10] Joseph A. Durlak, Joseph L. Mahoney, Amy M. Bohnert and Maria E. Parente.(2010). Developing and Improving After-School Programs to Enhance Youth's Personal Growth and Adjustment. A Special Issue of AJCP, 45(3\&4), pp. 285-293. 
International Journal of Social Science and Economic Research

ISSN: 2455-8834

Volume:05, Issue:08 "August 2020"

[11] Herselman, M., 2, Botha1, A., Dlamini, S., Marais, M. and Mahwai, N. (2018). 'Findings from a mobile tablet project implementation in rural South Africa'.15th International Conference on Mobile Learning 2019. Netherlands. 11-13 April. Utrecht: International Association for Development of the Information Society.

[12] Hoffman, E. (2008). Abraham Maslow: A Biographer's Reflection. Journal of Humanistic Psychology, 48 (4), pp.439-443.

[13] Matthew H. O. and Hergenhahn, B. R. (2011). An introduction to theories of personality. New Jersey: Prentice Hall/Pearson.

[14] Alderfer, C. P. (2007). A critique of Salancik and Pfeffer's examination of needsatisfaction.Theories.Administrative Science Quarterly, 22 (4), pp. 658-669.

[15] Yang, C.L., Hwang, M. \& Chen, Y.C. (2011).'An empirical study of the existence, relatedness, and growth (ERG) theory in consumer's selection of mobile value-added services'.African Journal of Business Management, 5(19), pp.7885-7898.

[16] Akinde, S. I.(2013). 'Retrenchment gale in banks: Post consolidation labour realities and the recurrent development question in Nigeria', in Nwabueze, N., Bameke, F. and Nnorom, C. P. (eds), Nigeria's banking industry The social sciences, Humanities and the human conditions: An impact appraisal., Univ. of Lagos: Department of sociology, pp. 229-244.

[17] Mabogunje. A. (1995).A Concept of Development: A working paper. Ibadan: Development Policy Centre.

[18] Onuma, N. (2016). Financial Allocation to Secondary Education in Nigeria: Implication for Students Performance.IOSR Journal of Research \& Method in Education (IOSR-JRME), 6 (3), pp.42-47.

[19] Africa Check (2017) Fact sheet: Nigeria's matriculation results between 2010 \& 2016. Available at: https://africacheck.org/ (Accessed: 17 December 2018).

[20] UNESCO -UNEVOC (2019) World TVET database - country profiles. Available at: https://unevoc.unesco.org/go.php (Accessed: 4 August, 2018).

[21] World Education Services. (2017). Education in Nigeria, Available at: https://wenr.wes.org/ (Accessed: 14 November 2019). 


\section{International Journal of Social Science and Economic Research}

ISSN: $2455-8834$

Volume:05, Issue:08 "August 2020"

[22] National Bureau of Statistics (2009a). Statistics of NECO Examination Results for Nov/Dec, 2007. Source: National Examinations Council, Minna (Accessed: 3 January, 2019).

[23] National Bureau of Statistics (2009b). Statistics of WAEC Examination Results for May/June, 2008. Source: West Africa Examination Council, Lagos (Accessed: 4 June, 2018).

[24] Ubah, M.C. 2004. Effect of street hawking on the academic performance of Students in social studies in Junior secondary schools in Nasarrawa State Nigeria. Journal of Research\& method in Education, 4 (4), pp. 18-22.1I

[25] Young, K. S. (1998). Internet Addiction: The emergence of a new clinical disorder. Cyber psychology \& Behavior, 7(1), 237-244.

[26] Martinez, A., Coker, C., McmahonS. D. and Cohen, J. (2016). Involvement in Extracurricular Activities: Identifying Differences in Perceptions of School Climate. The Educational and Developmental Psychologist, 1, pp.1-15.

[27] Lee, T., Cornell, D., Gregory, A., and Fan, X. (2011). High suspension schools and dropout rates for black and white students.Education and Treatment of Children, 34, pp. 167-192.

[28] Gregory, A., Cornell, D., Fan, X., Sheras, P., Shih, T.-H., and Huang, F. (2010). Authoritative school discipline: High school practices associated with lower bullying and victimization. Journal of Educational Psychology, 102(2), pp. 483-496.

[29] Buchmann, C. (2002). Measuring family background in international studies of education: Conceptual issues and methodological challenges' in A. C. Porter \& A. Gamoran (eds.) Methodological advances in cross-national surveys of educational achievement. Washington, DC: National Academy Press.

[30] Rasberry C. N., Lee, S.M., Robin, L., Laris, B.A., Russell, L.A., Coyle, K.K and Nihiser, A.J (2011). The association between school-based physical activity, including physical education, and academic performance: A systematic review of the literature. Preventive Medicine, 52, 10-20. Jun;52Suppl 1:S10-20. doi: 10.1016/j.ypmed.2011.01.027.

[31] Hillman C. H, Erickson K. I, Kramer, A. F. (2009). Be smart, exercise your heart: Exercise effects on brain and cognition. Nature Reviews Neuroscience, 9 (1), pp. 58-65.

[32] Agil, M. \& Ahmad, P. (2011). 'Use of the internet by research scholars and Post Graduate Students of the Science Faculty of Aligarh Muslim University', Library philosophy and practice.Available at: http:/unllib/unl.edu/lpp/ (Accessed: 2 February 2017). 
International Journal of Social Science and Economic Research

ISSN: 2455-8834

Volume:05, Issue:08 "August 2020"

[33] Ahmed, I \&Qazi, T. F. (2011). A look out for academic impacts of social networking sites: A student based perspective. African Journal of Business Management, 5, 12, pp.5022-5031.

[34] Ndaku, A.J. (2013). Impact of Social Media on the Students' Academic Performance: A Study of Relationship between Facebook Practice and Academic Performance of University Students. Asian Journal of Humanity and Social Science, 2 (2), pp. 1-7.

[35] Akanbi, M\&Akanbi, A. (2014). 'Influence of social media usage on self-image and academic performance among senior secondary school students in Ilorin West Local Government.Kwara State'.International Research Journal of Pure and Applied Physics, 4 (14), pp.42-50.

[36] Paul, M and Gelish, L (2011). College students' texting habit and their academic performance Procurement. Academic and Educational Leadership, 16 (2), pp. 67-72.

[37] Malaney, G. D. ( 2005). Student use of the internet.Journal of education, Technology and Systems, 33 (1), pp.53-66.

[38] Banquil, K., Chuna, N. A., Leano, G. A., Rivero, M. A., Bruce, C. A., Dianalan, S. N., Matienzo, A. R., \&Timog, N. U. (2009). Social networking sites affect one's academic performance adversely. Available at: http://www.ust.edu.ph. (Accessed: 13 April 2018).

[39] Gafni, R and Deri, M. (2012). Costs and benefits of facebook for undergraduate students.. Interdisciplinary Journal of Infrastructure, Knowledge and Management, 7 (1), pp. 45-

[40] Rouis, S., Limayem, E and Salehi-Sangari, M (2011). Impact of facebook usage on students' 'academic achievement: Role of self-regulation and trust. Electronic Journal Research of Educational Psychology, 9(3), pp.961-994.

[41] HuntingtonAfrica Check (2017).Fact sheet: Nigeria's matriculation results between 2010 \& 2016. Available at: https://africacheck.org/(Accessed: 17 December 2018). 